\title{
GLAGOLSKI OBLICI KAO IZRAZ GRAMATIČKIH KATEGORIJA (NA PRIMJERIMA HRVATSKOG, UKRAJINSKOG I RUSINSKOG JEZIKA) ${ }^{1}$
}

$\mathrm{U}$ analizi glagolskih gramatičkih kategorija pokušali smo objasniti razlike između glagolskog sustava ukrajinskog, rusinskog i hrvatskog jezika. Osobitosti u glagolskom sustavu svakog od ovih jezika ukazuju, s jedne strane, na promjene koje je jezik doživio u odnosu na ranije zajedničko praslavensko stanje, a s druge, na sličnosti koje potvrđuju da je riječ o srodnim jezicima koji su, bez obzira na višestoljetnu razdvojenost, sačuvali ne samo morfološke sličnosti nego i na sintaktičkoj i semantičkoj razini čuvaju zajedničke osobine.

Broj glagolskih kategorija isti je u sva tri jezika.

Svaka se gramatička kategorija odnosi na različiti dio komunikacijskog procesa s jedne strane, a s druge, svaka kategorija ima svoje osobitosti iskazivanja. Neke su stoga čisto morfološke, neke semantičke, a neke sintaktičke. Po tim se osobinama analizirani jezici ne razlikuju.

Na razini gramatičkih kategorija najveće su razlike na sinkronijskom planu u povezanosti pojedinih kategorija.

U ukrajinskom i rusinskom jeziku izrazita je povezanost kategorija vremena i vida. Njihova se veza temelji na općoj ideji vremena koju oni konkretiziraju na razne načine. U vremenskim značenjima ideja je vremena orijentirana na podudarnost radnje s trenutkom govora, tj. ima vanjsku usmjerenost, a u vidskim je značenjima ona unutarnja osobitost radnje. Dakle, gramemi vremena i vida iskazuju vanjske i unutarnje kvalitete dinamičkog obilježja, iskazanog glagolom.

Necjelovita radnja glagola nesvršenog vida može se podudarati sa svakim iskazom vremena. Cjelovita radnja svršenih glagola ili prethodi trenutku govora ili nastaje poslije njega. U ukrajinskom i rusinskom je jeziku to jasno izraženo time što svršeni glagoli imaju samo buduće i prošlo vrijeme (ukrajinski: напишу - написав, написала, зроблю - зробив, зробила; rusinski: напишем - написал, написала, зробим - зробел, зробела).

Kategorije vida i vremena razlikuju se i sredstvima izražavanja. Vidska značenja iskazuju sufiksi i prefiksi i osnovna im je klasifikacijska funkcija. Vremenska značenja prenosi fleksija usmjerena na iskazivanje sintaktičkih veza i semantičko-sintaktičkih odnosa među dijelovima rečenice.

U sva tri je jezika infinitiv oblik s najmanjim opterećenjem. Razlikuje samo kategorije prijelaznosti i vida. Upravo je pomanjkanje kategorija procesualnosti (kao vrijeme, način, stanje) ponukalo neke znanstvenike da posumnjaju u mjesto infinitiva unutar glagola (Kučerenko 2003: 35).

\footnotetext{
Članak je objavljen u časopisu Riječ 2, 2008.
} 
Imperativ je u sva tri jezika oblik s malo većim brojem relevantnih kategorija. U svima ima kategorije broja, lica, načina i stanja. Naravno, glagoli u imperativu razlikuju se i po prijelaznosti i vidu, ali oni, kao ni kategorija vremena, nisu relevantni, tj. ograničavajući za ovaj oblik. Zanimljivo je pitanje vremena imperativa. S obzirom na to da se radnja odvija poslije iskaza, tj. naredbe, odnosno upotrebe imperativa, moglo bi se zaključiti da je imperativ oblik budućeg vremena. Nepostojanje dihotomije, tj. još jednog oblika kojim bi se iskazivala opozicija u vremenu, neutralizira kategoriju vremena.

Nešto više glagolskih kategorija, ali u ograničavajućoj funkciji, sudjeluje u tvorbi oblika glagolskih priloga. U analiziranim jezicima glagoli nesvršenog vida tvore glagolske priloge sadašnjeg vremena, a glagoli svršenog vida samo oblik prošlog vremena. Dakle, ovdje je kategorija vida ograničavajuća. Ovi oblici ni u jednom analiziranom jeziku nemaju mogućnost razlikovati rod, broj, lice, što su osobine koje ih približavaju prilozima.

Aktivni glagolski pridjevi koji su zadržali osobine pridjeva u hrvatskom jeziku ne postoje. U ukrajinskom jeziku postoje aktivni glagolski pridjevi sadašnjeg i prošlog vremena (палаючий, дрімаючий; зів'ялий, зрошений). Ipak, i u ukrajinskom se jeziku rijetko upotrebljavaju, pogotovo u svakodnevnom govoru. Puno su češći pasivni glagolski pridjevi (посіяний, писаний, застосовуваний, загоєний, куплений, зроблений, розбитий, витерmий), što dokazuje činjenica da je njihov suodnos u učestalosti upotrebe u suvremenome ukrajinskom jeziku 5:1 (Bilodid 1969:89). Osim kategorije vremena ograničavajuću ulogu imaju kategorije prijelaznosti i vida, jer se aktivni glagolski pridjevi prošlog vremena tvore od neprijelaznih glagola svršenog vida, a aktivni glagolski pridjevi sadašnjeg vremena mogu biti oblikovani od glagola nesvršenog vida. Ovi su oblici zadržali obilježja pridjeva, pa tako razlikuju rod, broj i padež.

U hrvatskom jeziku postoji glagolski pridjev radni ili particip perfekta koji je izgubio kategoriju padeža kao pridjevsku osobinu. Zadržao je kategoriju roda (i u jednini i u množini) te kategoriju broja (bacao, bacala, bacalo, bacali, bacale, bacala, vidio, vidjela, vidjelo...). U ukrajinskim gramatikama on se naziva oblikom prošlog vremena i bitno se razlikuje od aktivnoga glagolskog pridjeva, koji se, premda nije jako čest i uobičajen, ipak upotrebljava u tom jeziku (oblik prošlog vremena: співав, співала, співало, співали, співати, aktivni glagolski pridjev: співаючий, співаюча, співаюче, співаючі-співаючого, співаючому...). Glagolski pridjev trpni u hrvatskom i ukrajinskom se jeziku tvori samo od prijelaznih glagola. Dakle, ovdje je kategorija prijelaznosti ograničavajuća. Glagolski pridjevi imaju kategoriju roda i broja te pridjevsku kategoriju padeža. Kategorije vida, vremena, načina nisu relevantne u tvorbi ovog oblika, a kategorija stanja «matična» je kategorija.

Rusinski jezik je potpuno pojednostavio količinu oblika glagolskih pridjeva. Tako je u njemu danas moguć samo oblik glagolskog pridjeva trpnog. On se tvori uglavnom od prijelaznih glagola, ali češće nego u hrvatskom i ukrajinskom i od neprijelaznih glagola: чumaни, пречитани, писани; neprijelazni glagoli: поставани (Рано уж шицки були поставани), наєдзени, спаднути, злєкнути, премокнути, вигаснути, умарти.

U ukrajinskim se gramatikama posebno izdvajaju tzv. predikativni oblici na -no, -to. To su okamenjeni oblici glagolskih pridjeva srednjeg roda. Ni u jednom drugom slavenskom jeziku oni ne čine posebnu skupinu. U ovoj analizi oni nam samo mogu biti potvrda tezi da su pasivne konstrukcije uobičajenije u ukrajinskom nego u hrvatskom jeziku. Tvore se 
od prijelaznih glagola. S obzirom na to da su okamenjene tvorbe jednog oblika glagolskih pridjeva, nepromjenjivi su, tj. nemaju kategorije roda, broja, lica, vremena, načina. I za njih možemo reći da im je kategorija stanja «matična» kategorija. Iako su podrijetlom glagolski pridjevi, s vremenom su izgubili sve osobine pridjeva, ali se upravo zbog toga izdvajaju kao posebne tvorbe. Uz oblike infinitiva, oni su oblici s najmanjim kategorijalnim opterećenjem (написано, забито, зроблено, розглянуто. Ой у полі жито копитами збито, під білою березою козаченька вбито (nar. pjesma).

Bezlične tvorbe imaju nešto veći broj glagolskih kategorija. Kao i svi oblici glagola imaju kategoriju prijelaznosti i vida, ali one u ovim tvorbama nisu ograničavajuće. U oba su jezika to oblici glagola koji se upotrebljavaju u 3. 1. jednine prezenta, tako da im kategorije lica, broja, roda i vremena nisu relevantne, ali su ograničavajuće jer se bezlične tvorbe javljaju samo u tom obliku. Pripadnost bezličnim glagolima, proizlazi iz semantike, iako neki glagoli imaju i potpunu paradigmu (grmi, sviće, sijeva...).

Sva tri analizirana jezika imaju dva oblika kondicionala. Razlika je u tome što se u ukrajinskom jeziku oni zovu pogodbeni način sadašnjeg vremena i pogodbeni način prošlog vremena. Pogodbeni način prošlog vremena tvori se u ukrajinskom jeziku od glagola svršenog vida, dok u hrvatskom i rusinskom ograničenje po vidu ne postoji. Oblici kondicionala imaju kategorije broja i roda (osim u ukrajinskom i rusinskom u množini). U hrvatskom jeziku kondicional ima i kategoriju lica, jer, kao što smo rekli, ona se iskazuje aoristom pomoćnog glagola biti, a kako ukrajinski i rusinski jezik nemaju aorista, u ovom je obliku sačuvao samo okamenjeni oblik 2. lica jednine бu. A niti se u gramatikama ne naziva pomoćnim glagolom, nego česticom.

Razlika između rusinskog i ukrajinskog standardnog jezika je u tome što rusinski ima dvije varijante iskazivanja kako kondicionala, tako i perfekta. Jedan je način kada je subjekt iskazan, kondicional se tvori okamenjenom česticom bi, bez pomoćnog glagola (kao u standardnom ukrajinskom)

\section{Я би читал; ти би читал; вон би читал....}

Kad subjekt nije iskazan, kondicional se tvori uz pomoć oblika pomoćnog glagola biti (slično kao u hrvatskom)

Читал бим (читал би сом); читал бим (читал би ши); читал би...

Rusinski je blizak ukrajinskom i po tome da oblici kondicionala u množini ne razlikuju rod (jer ga ne razlikuje pridjev radni glagola, tj. ukrajinski oblik prošlog vremena).

Možda su najveće razlike između ukrajinskog, rusinskog i hrvatskog jezika u tvorbi budućeg vremena. Iako ukrajinski jezik ima tri, a hrvatski i rusinski dva oblika futura, ipak je značenjski riječ o $2: 1 \mathrm{u}$ korist hrvatskog. U semantičko polje hrvatskog futura I. možemo smjestiti sva tri oblika ukrajinskog budućeg vremena (напишу, буду писати, писатиму), a isto tako i oba oblika rusinskog futura (напишем, будзем писаи) jer svi iskazuju značenje radnje koja će se dogoditi poslije trenutka govora. Svi oblici razlikuju broj i lice. U ukrajinskom i rusinskom je jeziku kategorija vida ograničavajuća jer prosti oblik imaju samo glagoli svršenog vida, a složeni i sastavljeni samo nesvršeni vid, ali riječ je samo o ograničenju u tvorbi, a ne u značenju. 
Ukrajinski standardni jezik i rusinski nemaju futur II., dakle nemaju oblik koji bi iskazivao radnju koja će se dogoditi prije neke druge. U hrvatskom taj oblik, budući da mu je jedna od komponenti glagolski pridjev, razlikuje rod, broj i lice (budem pisao, budeš pisao, budeš pisala...).

Posebnost rusinskog jezika je u tome da se, iako već arhaizirana, sačuvala mogućnost tvorbe složenog budućeg vremena uz pomoć oblika futura glagola biti - буu i infinitiva glagola moći - мочи i infinitiva glagola koji se spreže: Думали же голєм будзем мочи лєжац у посцелї (И. Копч.-Кнеж.); Я нӥцда нє будзем мочи танцовац-подумал сом себе. (О. Коч.) (Ramač 2002:122). Takva bi se tvorba mogla zvati tročlana.

Kategorije koje sudjeluju u tvorbi oblika prezenta ne podudaraju se potpuno. Prezent u analiziranim jezicima ima lice i broj, ali u ukrajinskom i rusinskom je jeziku vid ograničavajuća kategorija jer se prezent može tvoriti samo od glagola nesvršenog vida.

U tvorbi oblika perfekta i pluskvamperfekta sudjeluju kategorije roda, broja i lica. Nijedna kategorija nije ograničavajuća, samo što u ukrajinskom i rusinskom jeziku oblici množine ne razlikuju rod, a lice se, zbog toga što je u ukrajinskom nestao pomoćni glagol u oblicima perfekta, pa tako i pluskvamperfekta, razlikuje samo u sintagmama sa zamjenicama, tj. sintaktički. Rusinski, kao i kod kondicionala, i ovdje ima dvije mogućnosti tvorbe:

\section{Я писал, ти писал...}

Писал сом, писал ши....

U hrvatskom jeziku postoje oblici imperfekta i aorista koji su tijekom vremena u istočnoslavenskim jezicima, pa tako i u ukrajinskom i rusinskom, nestali.

Iz provedenog pregleda realizacije glagolskih kategorija unutar glagolskih oblika možemo izvesti zaključke:

1. U analiziranim jezicima svaka glagolska kategorija sudjeluje različitim intenzitetom i različitim ograničenjima u tvorbi glagolskih oblika.

2. Broj glagolskih oblika nije isti. U ukrajinskom jeziku postoji veći broj glagolskih pridjeva, bezlične tvorbe na -no, -to, dok je hrvatski bogatiji vremenskim oblicima (futur II., aorist, imperfekt).

3. U sva tri jezika ograničavajuće su općeglagolske kategorije (kategorija vida i prelaznosti).

4. Glagolske kategorije češće imaju ograničavajuću ulogu u tvorbi glagolskih oblika u ukrajinskom i rusinskom jeziku.

5. Tako su oba jezika ograničena kategorijom vida u tvorbi glagolskih priloga. U ukrajinskom i rusinskom glagolski vid ima presudnu ulogu u tvorbi prezenta i prostog oblika futura (glagoli svršenog vida nemaju prezent, a glagoli nesvršenog vida ne tvore proste oblike futura).

6. Kategorija prijelaznosti ograničavajuća je u tvorbi glagolskog pridjeva trpnog u hrvatskom i ukrajinskom jeziku te u ukrajinskim bezličnim tvorbama na -no, -to.

7. Glagolski pridjevi aktivni (sadašnjeg vremena na $-u \check{c}--j u \check{c}-,-a \check{c}-$, $-j a \check{c}-$ te prošlog vremena na -l-) danas postoje samo u ukrajinskom jeziku. U njihovoj tvorbi ograničavajuću ulogu imaju kategorije prijelaznosti, vida i vremena. 
8. Osim toga, u svim analitičkim tvorbama u kojima je jedna od komponenti glagolski pridjev, tj. particip perfekta ili, kako navode ukrajinske gramatike, oblik prošlog vremena, oblici množine u ukrajinskom i rusinskom su jeziku ograničeni jednim rodom, tj. nekadašnjim oblikom muškog roda, jer je kategorija roda u množini atrofirala. 